2 DR. GAYAN BOWATTE (Orcid ID : 0000-0002-9577-9752)

3 DR. IRINA LEHMANN (Orcid ID : 0000-0001-8875-5587)

4

Article type : Letter to the Editor

7 Editor

: Robyn O'Hehir

8

To the Editor:

Key words: allergic sensitization; shower; bath; cream; children

\title{
Hygienic behavior and allergic sensitization in German adolescents
}

According to the "hygiene hypothesis", frequent baths/showers and antimicrobial components in personal care products can alter skin microflora (1), leading to immune system impairment and allergic sensitization (2). The human skin provides a vital protection against the external environment. While frequent washing of hands, frequent baths/showers and use of soap and detergents aggravate the degradation of skin epithelium barrier (3), excess moisturizing of the skin makes it more sensitive to breakdown and increases permeability to foreign agents. Furthermore, almost all personal care products contain antimicrobial agents such as triclosan and/or parabens, which have been reported to have immune modulating properties in skin tissues and have the potential to induce or augment allergic disease (4). A degraded skin barrier through frequent baths/showers may result in a higher absorption of these chemicals into the body. To our knowledge, to date, no study has investigated the association between personal hygiene habits, such as frequent baths/showers and use of skin creams, and allergic sensitization.

For the current analysis, we used data collected mainly at the 15-year follow-up of the German GINIplus and LISA cohorts. Ethical approval for both cohorts was granted by the local ethics committees and informed consent was obtained from all families. Study methods are described in Online Supplement S1 and a flow chart of study participants is provided in Figure S1. We investigated cross-sectional associations of 1) having frequent baths/showers and 2) use of facial or 3) body cream on allergic sensitization to aero- and food-allergens while adjusting for potential confounders. Allergic sensitization was defined as a specific IgE value above $0.35 \mathrm{kU} / \mathrm{L}$ against a This is the author manuscript accepted for publication and has undergone full peer review but has not been through the copyediting, typesetting, pagination and proofreading process, which may lead to differences between this version and the Version of Record. Please cite this article as doi: $10.1111 /$ all.13492 
battery of 14 allergens. Our main analysis included subjects without "current allergies", defined as parent report of doctor diagnosis of asthma, eczema or allergic rhinitis during the last 12 months at the age of 15 years. The reason behind exclusion of participants with "current allergy" was to reduce impact of reverse causation. It is likely that people who already had "current allergies" may have changed their bathing habits and use of cream. For example, someone already has eczema may use excessive amount of body creams compared to a person without eczema. Additionally, we repeated the analyses for subjects who did not report ever allergy and for the complete population. We also checked whether the associations were modified by sex.

The majority of participants (52.0\%) were living in the Munich area. Three percent reported having less frequent (once per week or more rarely) baths/showers, 26\% - never using facial cream, and $35.2 \%$ - never using body cream. The prevalence of current aero- and food-allergen sensitization was $45.7 \%$ and $10.9 \%$, respectively (Table 1 ). Of the 15 -year participants $13.9 \%$ reported current allergy.

In our main analysis concerning adolescents without current allergies we observed a protective effect for having baths/showers less than or equal to once per week and aeroallergen sensitization, compared to having baths/showers every day (aOR $0.5195 \% \mathrm{CI} 0.27,0.98$ ) (Table 2). However, these associations were no longer significant after participants with ever allergy were excluded. Results for the complete cohort is given in Table S2. There was no evidence of an association between use of facial or body cream and allergic sensitization (Table 2). Further, we did not observe an association between having frequent baths/showers and food allergen sensitization (Table 1). Even though females were more likely to have frequent baths/showers and use facial/body creams, we observed no evidence for a modifying effect by sex for the effects of having frequent baths/showers or use of creams on allergic sensitization (Table $\mathrm{S} 3,4 \& 5$ ).

We observed a significant protective effect of having less frequent baths/showers and aero allergen sensitization in adolescents who did not report current allergies. This may be explained by less damage to the skin barrier and maintenance of healthy population of commensal microbiome on the skin in adolescents having less frequent showers/baths. Hygiene habits, including use of soap and detergents in baths/showers, accelerate epidermal barrier breakdown and results in an elevated $\mathrm{pH}$ level in the stratum corneum. A sustained increase of skin $\mathrm{pH}$ can cause damage to skin proteins and lipids. This may cause tightness, dryness, barrier damage, irritation and itching, allowing entry of foreign agents such as environmental allergens into the skin, which can then increase skin immune responses (5). Animal studies that used mechanical disruption of skin and allergen exposure have shown elevated antigen-specific $\operatorname{IgE}$ and $\operatorname{IgG1}$ responses in skin (6); similar mechanisms can be expected in damaged human skin. Frequent baths/showers can influence microbiome diversity on skin epithelial cells, which leads to an altered immune response. These effects have been seen in some 
67 infant studies, but there is limited evidence for the immunoregulation and skin microbiome 68 association in adults (2).

69 To our knowledge, there is no evidence in the published literature of the association between frequent 70 baths/showers, as well as use of creams, and allergic sensitization. Nevertheless, some studies have 71 investigated urine levels of parabens and triclosan in relation to allergic sensitization. Two US studies 72 found that higher triclosan concentrations were associated with increased odds of food sensitization in 73 children; one found the association only in children with eczema (7) and other only in males (8). A 74 Norwegian study reported that urinal triclosan was associated with allergic sensitization against aeroallergens, but not against food allergen (9). Although some studies reported a link between triclosan and food allergen sensitization we did not find any associations between frequent baths or use of creams, and food allergen sensitization.

The strengths of our analysis include the large population size, prospectively collected data on allergic outcomes and the availability of detailed information on potential confounders. Although the GINIplus and LISA cohorts are both prospective birth cohort studies, we do not have prospectively collected data on personal hygiene habits and use of creams. Given this limitation and even though we excluded participants with current allergy, we cannot completely rule out reverse causation as a driver of the observed associations. Similarly, the effects we observed cannot be ascribed to the frequency of baths/showers alone, since we do not have information on the use of personal care products such as soap, shampoo, etc. Also, there is a possibility of chance findings of significant associations.

Our study is the first to shed light onto the associations between having frequent baths/showers and use of creams, and allergic sensitization. In the general population, adolescents without allergies who have less frequent baths/showers had a protective effect against aeroallergen sensitization. Use of facial or body creams was not associated with allergic sensitization. Further, sex was not an effect modifier of these associations.

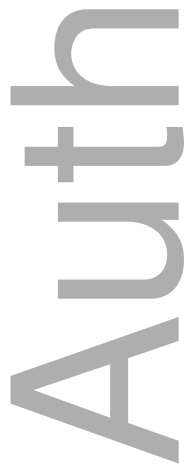

Table 1: Study characteristics of the subjects from GINIplus and LISA cohorts used for this statistical modeling $(n=2,755)$ 


\begin{tabular}{|c|c|c|c|}
\hline \multicolumn{2}{|c|}{ Characteristics of the study sample } & \multirow{2}{*}{$\begin{array}{r}\text { Frequency } \\
1,433\end{array}$} & \multirow{2}{*}{$\begin{array}{l}\% \\
52.01\end{array}$} \\
\hline Study area & Munich & & \\
\hline & Leipzig & 272 & 9.87 \\
\hline & Bad Honnef & 113 & 4.10 \\
\hline & Wesel & 937 & 34.01 \\
\hline Study & GINI plus observation & 897 & 32.56 \\
\hline & GINI plus intervention & 891 & 32.34 \\
\hline & LISA & 967 & 35.10 \\
\hline Sex & male & 1,385 & 50.27 \\
\hline & female & 1,370 & 49.73 \\
\hline Current aller & no & 2,256 & 86.11 \\
\hline 15 years $^{\dagger}$ & yes & 364 & 13.89 \\
\hline Ever reported & no & 1,483 & 53.83 \\
\hline allergy $^{\S}$ & yes & 1,272 & 46.17 \\
\hline Socio-economi & low & 166 & 6.03 \\
\hline status* & medium & 869 & 31.54 \\
\hline & high & 1,720 & 62.43 \\
\hline Parent atopy & no & 1,099 & 39.89 \\
\hline & yes & 1,656 & 60.11 \\
\hline Having baths/ & never/ less than once per week/ once per week & 68 & 2.47 \\
\hline showers & 2-6 times per week & 1,537 & 55.79 \\
\hline & every day & 1,150 & 41.74 \\
\hline Use of facial & never & 704 & 26.00 \\
\hline cream & often & 1,206 & 44.00 \\
\hline & every day & 825 & 30.16 \\
\hline Use of body & never & 975 & 35.60 \\
\hline cream & often & 1,489 & 54.36 \\
\hline 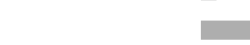 & every day & 275 & 10.04 \\
\hline Aeroallergen & no & 1,497 & 54.34 \\
\hline sensitization $^{\ddagger}$ & yes & 1,258 & 45.66 \\
\hline Food allergen & no & 2,455 & 89.11 \\
\hline sensitization $\|$ & yes & 300 & 10.89 \\
\hline Aero or food & no & 1,457 & 52.89 \\
\hline $\begin{array}{l}\text { allergen } \\
\text { sensitization }\end{array}$ & yes & 1,298 & 47.11 \\
\hline
\end{tabular}


$98 *$ defined as the highest number of years of school education of either parent: $<10$ years vs $=10$ years 99 vs $>10$ years, according to the German educational system

$100 \$$ defined as parent's eczema, allergic rhinitis or asthma before birth of child

$101 \S$ defined as parent report of doctor diagnosis of asthma, eczema or allergic rhinitis ever during 3-15

102 years of age
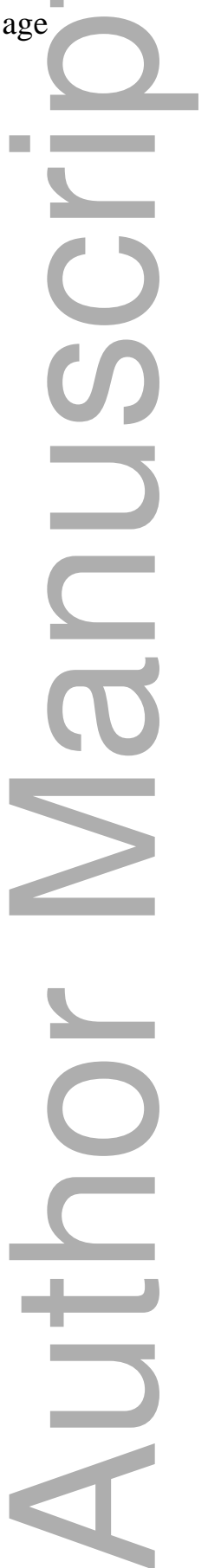
$\dagger$ defined as parent-report of doctor diagnosis of asthma, eczema or allergic rhinitis during the last 12 months at 15 years of age

$¥$ defined as specific IgE value above $0.35 \mathrm{kU} / \mathrm{L}$ against SX1 allergens: house dust mites, cats, dogs, mold, birch, rye, mugwort and timothy grass

" defined as specific IgE value above $0.35 \mathrm{kU} / \mathrm{L}$ against FX5 allergens: milk, peanut, eggs, soya, cod, wheat flour

\# defined as specific IgE value above $0.35 \mathrm{kU} / \mathrm{L}$ against SX1 or FX5 allergens

Table 2: Association between having baths/showers and use of creams, and allergic sensitization in adolescents without current allergies ${ }^{\S}$ (allergic sensitization $\mathrm{N}=2,255$; facial cream N =2,241; body cream $\mathrm{N}=2,244$ )

\begin{tabular}{|c|c|c|c|c|c|c|c|}
\hline & \multicolumn{2}{|c|}{$\begin{array}{l}\text { Aero/food } \\
\text { allergen } \\
\text { sensitization }\end{array}$} & \multicolumn{2}{|c|}{$\begin{array}{l}\text { Aeroallergen } \\
\text { sensitization }\end{array}$} & \multicolumn{2}{|c|}{$\begin{array}{l}\text { Food allergen } \\
\text { sensitization }\end{array}$} & $\mathrm{n}$ \\
\hline Baths/showers frequency & $\mathrm{OR}^{*}$ & $95 \% \mathrm{CI}$ & $\mathrm{OR}^{*}$ & $95 \% \mathrm{CI}$ & $\mathrm{OR}^{*}$ & $95 \% \mathrm{CI}$ & \\
\hline ery day & \multicolumn{2}{|c|}{$\begin{array}{l}\text { Reference } \\
\text { category }\end{array}$} & \multicolumn{2}{|c|}{$\begin{array}{l}\text { Reference } \\
\text { category }\end{array}$} & \multicolumn{2}{|c|}{$\begin{array}{l}\text { Reference } \\
\text { category }\end{array}$} & 912 \\
\hline 2-6 times per week & 1.12 & $0.94,1.34$ & 1.11 & $0.93,1.32$ & 1.07 & $0.78,1.47$ & 1,290 \\
\hline $\begin{array}{l}\text { Never/ less than once per } \\
\text { week/ once per week }\end{array}$ & 0.54 & $0.28,1.02$ & $\mathbf{0 . 5 1}$ & $0.27,0.98$ & 1.27 & $0.49,3.31$ & 53 \\
\hline Facial cream & \multirow{2}{*}{\multicolumn{2}{|c|}{$\begin{array}{l}\text { Reference } \\
\text { category }\end{array}$}} & \multirow{2}{*}{\multicolumn{2}{|c|}{$\begin{array}{l}\text { Reference } \\
\text { category }\end{array}$}} & \multirow{2}{*}{\multicolumn{2}{|c|}{$\begin{array}{l}\text { Reference } \\
\text { category }\end{array}$}} & 573 \\
\hline Never & & & & & & & \\
\hline Often & 1.03 & $0.82,1.27$ & 1.02 & $0.82,1.26$ & 1.11 & $0.76,1.62$ & 988 \\
\hline Every day & 1.00 & $0.77,1.29$ & 0.96 & $0.74,1.25$ & 0.98 & $0.62,1.56$ & 680 \\
\hline Body cream & \multicolumn{2}{|c|}{$\begin{array}{l}\text { Reference } \\
\text { category }\end{array}$} & \multicolumn{2}{|c|}{$\begin{array}{l}\text { Reference } \\
\text { category }\end{array}$} & \multicolumn{2}{|c|}{$\begin{array}{l}\text { Reference } \\
\text { category }\end{array}$} & 800 \\
\hline Often & 0.98 & $0.79,1.21$ & 1.03 & $0.83,1.27$ & 0.82 & $0.57,1.19$ & 1,227 \\
\hline Every day & 0.88 & $0.62,1.25$ & 0.85 & $0.59,1.21$ & 1.00 & $0.55,1.83$ & 217 \\
\hline
\end{tabular}


${ }^{\S}$ defined as parent report of doctor diagnosis of asthma, eczema or allergic rhinitis during the last 12 months at 15 years of age

*Adjusted for study center, cohort, sex, socio-economic status and parental history of allergy

OR: Odds Ratio, CI: Confidence Intervals, $\mathrm{n}=$ number of participants in each category

\section{References}

1. Elaine L. Hygiene of the Skin: When Is Clean Too Clean? Emerging Infectious Disease journal 2001;7(2):225.

2. Lambrecht BN, Hammad H. The immunology of the allergy epidemic and the hygiene hypothesis. Nat Immunol 2017;18(10):1076-1083.

3. Cork MJ, Danby SG, Vasilopoulos Y, Hadgraft J, Lane ME, Moustafa M, et al. Epidermal barrier dysfunction in atopic dermatitis. J Invest Dermatol 2009;129(8):1892-1908.

4. Marshall NB, Lukomska E, Nayak AP, Long CM, Hettick JM, Anderson SE. Topical application of the anti-microbial chemical triclosan induces immunomodulatory responses through the S100A8/A9-TLR4 pathway. J Immunotoxicol 2017;14(1):50-59.

5. Ananthapadmanabhan KP, Moore DJ, Subramanyan K, Misra M, Meyer F. Cleansing without compromise: the impact of cleansers on the skin barrier and the technology of mild cleansing.

Dermatologic Therapy 2004;17:16-25.

6. De Benedetto A, Kubo A, Beck LA. Skin barrier disruption: a requirement for allergen sensitization? J Invest Dermatol 2012;132(3 Pt 2):949-963.

7. Spanier AJ, Fausnight T, Camacho TF, Braun JM. The associations of triclosan and paraben exposure with allergen sensitization and wheeze in children. Allergy and Asthma Proceedings 2014;35(6):475-481.

8. Savage JH, Matsui EC, Wood RA, Keet CA. Urinary levels of triclosan and parabens are associated with aeroallergen and food sensitization. The Journal of allergy and clinical immunology 2012;130(2):453-460.e457.

9. Bertelsen RJ, Longnecker MP, Lovik M, Calafat AM, Carlsen KH, London SJ, et al. Triclosan exposure and allergic sensitization in Norwegian children. Allergy 2013;68(1):84-91. 
Authors - Gayan Bowatte, $\mathrm{PhD}^{1}$, Iana Markevych, $\mathrm{PhD}^{2,3}$, Marie Standl, $\mathrm{PhD}^{3}$, Shyamali C Dharmage, $\mathrm{PhD}^{1,4}$, Sibylle Koletzko, Prof. ${ }^{5}$, Irina Lehmann, $\mathrm{PhD}^{6}$, Carl-Peter Bauer, Prof. ${ }^{7}$, Tamara Schikowski, $\mathrm{PhD}^{8}$, Andrea von Berg, $\mathrm{MD}^{9}$, Dietrich Berdel, Prof. ${ }^{9}$, Joachim Heinrich, $\mathrm{PhD}^{2,3 *}$

${ }^{1}$ Allergy and Lung Health Unit, School of Population and Global health, University of Melbourne, Melbourne, Australia

${ }^{2}$ Institute and Clinic for Occupational, Social and Environmental Medicine, University Hospital, LMU Munich, Munich, Germany

${ }^{3}$ Institute of Epidemiology I, Helmholtz Zentrum München - German Research Center for Environmental Health, Neuherberg, Germany

${ }^{4}$ Murdoch Children's Research Institute, Melbourne, Australia

${ }^{5}$ Division of Paediatric Gastroenterology and Hepatology, Dr. von Hauner Children's Hospital Munich, Ludwig-Maximilians-University of Munich, Germany

${ }^{6}$ Department of Environmental Immunology/Core Facility Studies, Helmholtz Centre for Environmental Research - UFZ, Leipzig, Germany

${ }^{7}$ Department of Pediatrics, Technical University of Munich, Munich, Germany

${ }^{8}$ IUF-Leibniz Research Institute for Environmental medicine, Düsseldorf, Germany

${ }^{9}$ Research Inștitute, Department of Pediatrics, Marien-Hospital Wesel, Wesel, Germany

Word count: 1033

*Corresponding author:

Dr. Joachim Heinrich

Institute and Clinic for Occupational, Social and Environmental Medicine, University Hospital, LMU Munich

Ziemssenstraße 1

81337 Munich

Germany

Phone: +4989440053251

Email: Joachim.Heinrich@med.uni-muenchen.de 


\section{Funding}

The GINIplus study was mainly supported for the first 3 years by the Federal Ministry for Education, Science, Research and Technology (interventional arm) and Helmholtz Zentrum Munich (former GSF) (observational arm). The 4, 6 and 10-year follow-up examinations of the GINIplus study were covered from the respective budgets of the 5 study centres (Helmholtz Zentrum Munich (former GSF), Marien-Hospital Wesel, LMU Munich, TU Munich and from 6 years onward also from IUFLeibniz Research-Institute for Environmental Medicine) and a grant from the Federal Ministry for Environment (IUF, FKZ 20462296). The LISA study was mainly supported by grants from the Federal Ministry for Education, Science, Research and Technology and in addition from Helmholtz Zentrum Munich (former GSF), Helmholtz Centre for Environmental Research-UFZ, Leipzig, Marien-Hospital Wesel, Pediatric Practice, Bad Honnef for the first 2 years. The 4, 6 and 10year follow-up examinations of the LISA study were covered from the respective budgets of the involved partners (Helmholtz Zentrum Munich (former GSF), Helmholtz Centre for Environmental ResearchUFZ, Leipzig, Marien-Hospital Wesel, Pediatric Practice, Bad Honnef, IUF-Leibniz-Research Institute for Environmental Medicine) and in addition by a grant from the Federal Ministry for Environment (IUF, FKZ 20462296). The recent 15-year follow-up examinations of the GINIplus and LISA studies were supported by the Commission of the European Communities, the $7^{\text {th }}$ Framework Program (MeDALL project) and the Mead Johnson and Nestlé companies (GINIplus only). Gayan Bowatte is supported by Centre for Air pollution, energy and health Research (CAR) and National Health and Medical Research Council Australia funded Centre for Research Excellence. The funding sources were not involved in the design of the study, collection, analysis and interpretation of data, writing of the report and decision to submit the article for publication.

\section{Acknowledgements}

We thank all children and parents for their cooperation, and all technical and administrative support staff and medical and field work teams. We are also grateful to all members of the GINIplus and LISA Study Groups.

\section{Author contributions}

GB conducted the analyses, interpreted the data, drafted the initial manuscript, and revised the manuscript. IM preprocessed the data. IM, MS, SD and JH contributed to the design of the analysis and interpretation of the data. MS, SK, IL, CPB, TS, AvB and DB contributed to the data collection and reviewed the manuscript. JH initiated and supervised the analysis. All authors approved the final manuscript as submitted and agree to be accountable for this work. 


\section{Conflict of interests}

None.
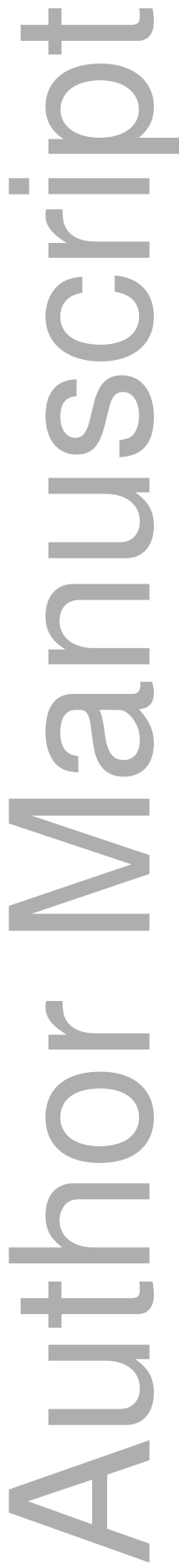

This article is protected by copyright. All rights reserved 


\section{University Library}

\section{- M M N E R VA A gateway to Melbourne's research publications}

Minerva Access is the Institutional Repository of The University of Melbourne

Author/s:

Bowatte, G;Markevych, I;Standl, M;Dharmage, SC;Koletzko, S;Lehmann, I;Bauer, CP;Schikowski, T;von Berg, A;Berdel, D;Heinrich, J

Title:

Hygienic behavior and allergic sensitization in German adolescents

Date:

2018-09-01

Citation:

Bowatte, G., Markevych, I., Standl, M., Dharmage, S. C., Koletzko, S., Lehmann, I., Bauer, C. -P., Schikowski, T., von Berg, A., Berdel, D. \& Heinrich, J. (2018). Hygienic behavior and allergic sensitization in German adolescents. ALLERGY, 73 (9), pp.1915-1918. https:// doi.org/10.1111/all.13492.

Persistent Link:

http://hdl.handle.net/11343/284075 